\title{
Dinamika Penyelenggaraan Pilkada Serentak Tahun 2020 Di Tengah Pandemi Covid-19
}

\section{Dynamics of Simultaneous Local Elections in 2020 During Covid-19 Pandemic}

\author{
Wahyu Widodo ${ }^{1}$, Werijon $^{2}$, Agung Setiawan ${ }^{3}$ \\ ${ }^{1-3}$ Naval Staff and Command College, Jakarta, Indonesia \\ *corresponding author E-mail: mazndan.7479@gmail.com
}

Received: juny 21, 2021; In Revised: August 8, 2021; Accepted: August 11, 2021

\begin{abstract}
ABSTRAK
Di masa pandemi COVID-19, kemungkinan konflik dalam Pilkada Serentak sulit untuk diabaikan; bahkan cenderung berkembang. Pada dasarnya, konflik muncul sebagai akibat dari kurangnya perencanaan dan pelaksanaan penyelenggara pemilu, peraturan yang membingungkan, tanggung jawab yang tumpang tindih dan interpretasi undang-undang yang beragam, dan ketidakmampuan dalam menangani masalah teknis pemilu. Penelitian ini bertujuan untuk menganalisis dinamika penyelenggaraan Pilkada Serentak Tahun 2020 di tengah pandemi COVID-19. Penelitian ini menggunakan desain kualitatif dengan pendekatan deskriptif. Pengumpulan data dilakukan dengan menggunakan teknik literature review dari beberapa sumber jurnal terkait. Berdasarkan hasil kajian dengan Konsep Resolusi Konflik, diperoleh kesimpulan bahwa potensi konflik yang muncul dalam pilkada serentak 2020 yaitu adanya politik uang yang disamarkan sebagai bantuan untuk penanggulangan COVID-19, rendahnya partisipasi pemilih karena ketakutan masyarakat terhadap penularan virus COVID-19, serta lemahnya manajemen teknis pemilu yang mengakibatkan harus dilakukannya Pemungutan Suara Ulang di beberapa wilayah di Indonesia. Resolusi konflik untuk menghilangkan budaya money politics yaitu dengan pendidikan politik yang harus dimulai dari partai politik. Sementara, untuk meminimalisir Pemungutan Suara Ulang maka penyelenggara pemilu harus mempersiapkan manajemen teknis secara keseluruhan dengan baik mulai dari perencanaan, pengorganisasian, pelaksanaan hingga evaluasi keseluruhan proses penyelenggaraan pemilu.
\end{abstract}

Keywords: Pilkada serentak, resolusi konflik, COVID-19, money politics.

\section{ABSTRACT}

During the COVID-19 pandemic, it is difficult to ignore the possibility of conflict in the simultaneous local elections; in fact, it tends to grow. Fundamentally, conflicts arise as a result of lack of planning and implementation of electoral management bodies, confusing regulations, overlapping responsibilities and multiple interpretations of laws, and inability to deal with technical electoral 
issues. This study aims to examine the dynamics of holding the 2020 simultaneous local elections in the midst of the COVID-19 pandemic. This study employs a qualitative design with a descriptive approach. Data collection was carried out using literature review techniques from several related journal sources. According to the results of the study with the concept of conflict resolution, the potential conflicts that emerged in the 2020 simultaneous local elections, including the existence of money politics disguised as assistance for overcoming COVID-19, low voter participation due to public fear of the transmission of the COVID-19 virus, and weak technical elections management which resulted in the need for re-voting in several regions in Indonesia. Therefore, it can be conluded that conflict resolution to eliminate money politics culture can be done by conducting political education which must be started from political parties. Meanwhile, to minimize re-voting, Electoral Management Bodies must prepare overall technical management well from planning, organizing, implementing to evaluating the entire process of organizing the election.

Keywords: Simultaneous local elections, conflict resolution, COVID-19, money politics.

\section{INTRODUCTION}

General elections (PEMILU) held at national level to elect the president and vice president, along with legislative members, while local elections (PILKADA) held at local level to elect regional heads, such as governors, regents, or mayors (Anggraini, Afrizal \& Indradding, 2019). By Sarjan et al (2020), holding the local election during COVID-19 pandemic is an issue. According to Adrianus Meliala in Rahmiati 2020, assumptions are made to see the possibility or social conflicts during election. Physical contact, crowds, negative feelings, and social media effects must be avoided during the election process. The effort to minimize conflicts can be done by eliminating manual voting to e-voting, the conflicts caused by Local Elections implementers, participants or other parties during pre-voting stage and differences of opinions and values (Rahmiati 2020).

Conflicts is a situation where a person or party has different views, manifested in poor behaviour to achieve certain goal. It is an attempt to obtain or maintain certain values (Subakti, 1992). It is necessary to comprehend the core of democracy in multicultural country as Indonesia and society claims absolute truth in religion, morality, and culture also can cause conflict 
(Kuntjaraningrat, 1983). Conflicts occurred in interest of being in status quo or achieving certain changes (Ritzer \& Goodman, 2004). Meanwhile, the surrounding intensity of COVID-19 epidemic had no impact on the spread of the pandemic during National Election of France (Zeiton, Faron, et al. 2020).

The conflict resolution should end the conflict as mentioned by Mindes (2006). It is proven that conflict resolutions are able to solve differences between parties. Based on important aspects of social and moral development which require skills to negotiate, compromise, and cultivate justice. In the United States, mass casualty event may potentially occur among numerous social and economic changes. The theoretical perspective of politics shifts using state level data on population, historical voter turnout, and projected COVID-19 cases number coupled with national level data on voter participation by age group and COVID-19 fatality rates. The potential for significant political changes due to the disproportionate loss of older voter in key swing states in the months leading to the 2020 presidential election (Johnson, Pollock, and Rauhaus 2020). It is proven that there are certain conflicts could be happened if the election must be postponed. The conflicts that will be focused on this study are divided into potential and resolution. The purpose of this study to examine the dynamics of holding the 2020 Simultaneous Regional Head Elections in the midst of the COVID-19 pandemic.

The impact of the lockdown policy on voting behaviour during the COVID-19 pandemic significantly affected electoral outcomes. It is suggested that lockdown measures strongly lead citizen to rally around the local incumbent politicians (Giommoni and Loumeau, 2020). The COVID-19 presents a contradictory dynamic which is important issue to voters. To reduce the risk of getting infected more people than usually are opting to vote by mail, an especially important strategy for many members of communities who are at higher risk for COVID-19 infection and complications. Unfortunately, anticipated changes in COVID-19 on voting patterns has led to the promotion of voter suppression strategies (Norris and Gonzales 2020). 
POLITICON : Jurnal Ilmu Politik Vol.3 No.2 ; Hal 185 - 205

Website : http://journal.uinsgd.ac.id/index.php/politicon

ISSN : 2685-6670 ( Online )

The study conducted by Prabowo et al. 2020 that the government of Indonesia has made several detailed regulations and procedures regarding the implementation of the simultaneous regional head elections in order to prevent the emergence of new cluster of COVID-19 spread (Prabowo et al. 2020).

\section{RESEARCH METHOD}

This research is using both qualitative and analytical method. This research explains and analyzes causal relationships between society and the parties, focusing on the dynamics of holding Local Elections in 2020 during COVID-19 pandemic. According to Moleong in Royadi et al. 2019, qualitative research is a method that intends to understand the phenomenon based on experience of the research subject such as behavior, perceptions, motivations, action and so forth. Holistically and by way of descriptions in terms of word and languages in a special context that is natural and by utilizing various natural methods (Moleong, 2004) (Royadi et al. 2019). The concept of Conflict Resolution also used in this research as analytical tool. Thus, the research will contribute public to have a better understanding regarding the dynamics of Indonesian Simultaneous Local Elections in 2020.

The role of conflict resolution in determining whether certain forms of intragroup conflict are related to the appearance of other forms of conflict over time. It is indicated a negative and long-lasting impact of process conflict occurring early in the team's interaction (Greer, Jehn, Mannix 2008). It is suggested that process conflicts may be particularly susceptible to this emotionally because of the connotations of personal worth and respect that are challenged in process issues. Therefore, it is similarly to relationship conflict that has been found to have consistent negative effects on performance due in large part to the emotionality associated with such conflict (Greer and Jehn 2007).

The data were collected by Local Election implementers, participants, and other parties during pre-voting stage and regarding differences of 
POLITICON : Jurnal Ilmu Politik Vol.3 No.2 ; Hal 185 - 205

Website : http://journal.uinsgd.ac.id/index.php/politicon

ISSN : 2685-6670 ( Online )

opinions and values. The local elections have involved several political parties to achieve political power on it. Local political competition can create an effect not only at the provincial level, but also the national level. The central government must take serious concern in preventing pre-election dispute (International Crisis Group 2010). A normative legal method is used in this article to concentrating several acts and regulations having connectivity with the topic. It is also to seek the specific norm in article or clause that can potentially create a multi-interpretation meaning and finding the appropriate meaning to reduce the conflicts (Arnia 2018).

\section{RESULT AND DISCUSSION}

\section{Result}

By Ramlan Surbakti, conflict is a situation where a person or party has different views, manifested in poor behavior to achieve certain goal that only benefits one part based on the views or competitions, individually and generally between one and more subjects. It is an attempt to obtain and/or maintain certain values that one person or party held as a background or ideology they believe to be the most effective way (Subakti, 1992).

In Immanuel Kant Theory, a German philosopher (1724-1804), it is necessary to comprehend the core of democracy in multicultural country as Indonesia. He stated that if certain society claims absolute truth in religion, morality and/or culture, the result is conflict. As a multicultural country, the possibility of conflicts occurred between society is very high, knowing that Indonesia is rich with diversity not only by ethnicity but also racial and regional subcultures (Kuntjaraningrat, 1983).

In politic approach, conflicts occurred in interest of being in status quo conditions, or in interest of achieving certain change in certain conditions and/or situations. The parties with authorities, known as super ordinated and the opposed parties known as subordinated, will always fight for personal interest based on their own values which differs in terms of having authority 
and beliefs (Ritzer \& Goodman, 2004).

One of many ways to end conflict is by forming a conflict resolution. Mindes (2006, p.24) believes that conflict resolution is the ability to solve differences between conflicted parties. This is an important aspect of social and moral development which require each party to have skills in negotiating, compromising different values and opinions and cultivating justice between one another in terms of decision making. Based on the theory, it can be concluded that conflict resolution means an individual can solve problems occurred between parties. Conflict resolution recommends democratic and constructive ways point of view to solve problems or recruit a neutral third party to assist in place so that there will be final solutions approved by every parties involved.

The current issues that has been studied before this article are occur before 2021. Several articles were discussed about the cause and effect of postponed elections for more details can be seen in table 1 . The procedures of large-scale social restrictions (PSBB) has been declared since 24 April 2020 (Wijaya 2020). Some issues are implemented to hold the COVID-19 cases. The risks of COVID-19 during elections effected that the result of the election which is far from honest and transparent (Rosanti 2020). However, the postponed of the election may breakdown the democratic especially in presidential systems (James and Alihodzic 2020). The voter education is important during the election. the education video can be used as an educational material of the deaf voters (Fernandes et al. 2020). The government has made a regulations and procedures to limit mobilization and crowds in order to hold back the spread of coronavirus (Prabowo et al. 2020). Jokowi, the president of Indonesia has managing the pandemic on his agenda which prioritised the economy to uphold or strengthen an array of political and civil rights that are crucial to the equality of Indonesian democracy (Fealy 2020). 
Table 1. analysis of previous research

\begin{tabular}{|c|c|}
\hline Research & Cause and Effect \\
\hline Nursalim, P. M. (2019) & $\begin{array}{l}\text { Cause: Political noise in Indonesia raises the number of practical political actors } \\
\text { on social media. } \\
\text { Effect: Massive expressions have the potential to become myth. } \\
\text { In the last } 5 \text { years the Indonesia political issues become a trending in the social } \\
\text { media. It is explained as in terms of denotation to connotation. The words that } \\
\text { used within this period are cebong, kampret, komunis, and onta. }\end{array}$ \\
\hline Sandi et al. 2020 & $\begin{array}{l}\text { Cause: The democracy atmosphere implementation would be different from } \\
\text { previous over the years due to COVID- } 19 \text { pandemic as its prediction. } \\
\text { Effect: The regional election could be implemented by following the Protocol } \\
\text { Health Procedures with safe and healthy against COVID-19. }\end{array}$ \\
\hline Rosanti, R., 2020. & $\begin{array}{l}\text { Cause: The many risks that a COVID-19 pandemic can cause during elections, } \\
\text { which will be far from honest and transparent. } \\
\text { Effect: some consequences of formally delaying the holding of elections which } \\
\text { vary by type of regime, and electoral cycle can be affected by the pandemic. }\end{array}$ \\
\hline Marisa et al. 2020. & $\begin{array}{l}\text { Cause: a projection and how the development of elections during COVID-19 } \\
\text { pandemic. The election is known to a public as a venue for the election of regional } \\
\text { heads who will serve or lead. } \\
\text { Effect: Since the election has been postponed for } 3 \text { months, the step was criticized } \\
\text { because it was considered ignoring COVID- } 19 \text { pandemic. }\end{array}$ \\
\hline James and Alihodzic, 2020. & $\begin{array}{l}\text { Cause: Holding regular elections is an essential feature of democratic practices. } \\
\text { The case for postponing elections is often made during emergency situations. } \\
\text { Effect: The postponement will break institutional certainty, which could pose } \\
\text { threats of democratic breakdown especially in presidential systems. }\end{array}$ \\
\hline Fernandes et al. 2020 & $\begin{array}{l}\text { Cause: The election of regional heads in } 2020 \text { coincided with the outbreak of the } \\
\text { COVID-19 virus in Indonesia. Voter education is an important part that must be } \\
\text { implemented in the election phase only uses socialization through mass media. } \\
\text { Effect: The education video is made to meet valid and effective criteria so that can } \\
\text { be used for educational materials of voters to the deaf. }\end{array}$ \\
\hline Kamil et al. 2021 & $\begin{array}{l}\text { Cause: The government has especially recommended Stay at Home and the } \\
\text { implementation of PSBB in various region. The main concern is when the election } \\
\text { of regional leaders to the general chairman. } \\
\text { Effect: Even though the safeguard regulation has been declared, it is not } \\
\text { considered safe in the current pandemic. The use of a blockchain-based E-voting } \\
\text { system to help tackle election unrest during COVID-19. }\end{array}$ \\
\hline $\begin{array}{l}\text { Prabowo, Syafri, Juanda } \\
2020\end{array}$ & $\begin{array}{l}\text { Cause: The COVID-19 forces the government to limit both mobilization and } \\
\text { crowds in order to hold back the spread of the coronavirus. } \\
\text { Effect: The government of Indonesia has made several detailed regulations and } \\
\text { procedures regarding the implementation of the simultaneous regional head } \\
\text { elections in order to prevent the emergence of new cluster of COVID-19 spread. }\end{array}$ \\
\hline Fealy 2020. & $\begin{array}{l}\text { Cause: Jokowi has grappled with managing the pandemic and salvaging key of his } \\
\text { agenda. He also consistently prioritised the economy over public health and } \\
\text { abandoned commitments to uphold or strengthen an array of political and civil } \\
\text { rights that are crucial to the quality of Indonesian democracy. } \\
\text { Effect: Jokowi's decision to support the nominations of his son and son-in-law in } \\
\text { mayoral elections in two major cities bringing accusations of dynasticism and } \\
\text { elitism. }\end{array}$ \\
\hline
\end{tabular}

Source : processed by researchers 2021

\section{DISCUSSION}

\section{Conflict Potentials of Simultaneous Local Elections in 2020}

In simple terms, democracy interpreted as "government of the people, by the people, and for the people". However, it is complicated to realize because democracy requires long process and critical stages, taking the example of democratic consolidation process. By Whitehead (1989), democratic consolidation is one way to increase the commitment of all levels 
of society within democratic ground. This is a political process that takes place not only at the procedural level of political institutions, but also at the social level. Democracy will be strengthened if political, economic, state and civil society actors (political society, economic community, state, and civil society) presents democratic activities as the basic of gaining power (Zuhro, 2019).

The purpose of UU No 7 of 2017 is based on the embodiment of a democratic and integrated constitutional system to ensure legal certainty and efficient general elections. In accordance with Pancasila and 1945 Constitution of Republic of Indonesia, elections aimed to realize public aspirations, and to establish ideal governmental representatives.

The constitution explains, "General Elections are held to elect members of Indonesian Legislative Representative, as House of Representatives (DPR), Regional Representative Board (DPD), President and Vice President and Regional House of Representatives (DPRD)", held directly, publicly, freely, confidentially, honestly and fair every five years (Article 22E paragraph (2) of the 1945 Constitution). While the implementation of Local Elections is for "Governors, Regents, and Mayors respectively as representative of provincial, district, and city regional governments to be democratically elected" (Article 18 paragraph (4) of the 1945 Constitution).

As the basic of democracy, General Election provides great momentum for public to address their aspirations and ambitions to political parties, to elect their best representatives peacefully, along with their president and/or vice president. The Nation's ability to organize politics and governmental process based on the founders of the nation is necessary to hold general elections (legislative elections, regional head elections, and presidential elections) and to hold the democratic system. Although the Constitution guarantees political rights and civil liberties, General Election has not been able to deliver Indonesian public to the true sovereignty (Zuhro, 2019). Conflict is also defined as the clash of interest over national values for a certain period of time and occurs between two parties. The parties could be 
POLITICON : Jurnal Ilmu Politik Vol.3 No.2 ; Hal 185 - 205

Website : http://journal.uinsgd.ac.id/index.php/politicon

ISSN : 2685-6670 ( Online )

organizational groups, countries, groups of countries, or organizations which demands realization of their national interests. Each conflict has basic elements, allowing us to form conflict mapping where there will be an intervention of third party is expected to find a way to resolve it (Wehr, 1979).

Holding regular election is an essential feature of democracy practices. The case for postponing elections is often made during emergency situations. Despite the critical nature of the issue for democracy, peace, and security, there has been sparse academic literature on election postponement. Case study by James and Alihodzic, 2020 proved that holding elections during natural disasters will often lead to severely compromised opportunities for deliberation, contestation, participation, and election management quality. The postponement will break institutional certainty, which could pose threats of democracy breakdown especially in presidential systems. The best available safeguards for electoral integrity during natural disasters include the introduction or expansion of low-tech solutions such as early voting, strengthened risk management, but also transparency and inclusivity in decision making. There are important lessons for the broader scholarship and practice of democracy during emergency situations (James and Alihodzic 2020).

Voting is the defining act for a democracy. Voting is only meaningful if public deliberation is grounded in veritable and equitable information. The public sphere on Twitter is politically heterogenous and the majority liberal and conservative alike advocates for wearing masks and vote by mail. A small group of conservative users push anti-mask and voter fraud narratives (Chen, et al. 2021).

Globally, the USA has recorded the highest number of COVID-19 cases and deaths, one and still needs to simultaneously respond to another looming potential pandemic. In 2017, the US food and drug administration banned use of antibiotics as growth promoters in livestock-a welcome move, following several other countries. It is banned due to overuse or antibiotics in human, 
continuing misuse in agriculture, and the dearth of antimicrobials in the development pipeline. The COVID-19 pandemic is a wake-up call that global collaboration is the most effective way to tackle global health threats (Strathdee, et al. 2020). The COVID-19 cases negatively affected Trump's vote share in America. A simple counterfactual analysis suggests that Trump would likely have won re-election if COVID-19 cases had been 5 percent lower. In the other hand, COVID-19 incidence has a positive affect on voter's mobilization, helping Biden win the presidency (Baccini, et al. 2021).

The most common conflict potentially occur in 2020 Local Elections is money politics disguised as aid for COVID-19 prevention. Another potential is the low participant due to elders and vulnerable participants are prohibited to vote in prevention of COVID-19 spread. Organizers are also asked to be wary of apathy participants since people are more focused on health and the economy during the pandemic (Sucipto, 2020).

Additionally, the 2020 Local Elections fraud occurred at the verification stage of individual candidates. This is the most critical stage in determining whether a candidate will be promoted through elections. Shortcomings at this stage are possible, based on the experience of previous occasions, verification scenes of individual couples has caused many disputes. (Jehamun, 2020)

By Sarjan et el (2020), the postpone of various stages in Local Elections during pandemic leads to both good and bad consequences in the implementations. The benefits of this suspension, for example, is to allow independent candidates to set the terms of support as individual candidates. Political parties can also enjoy some relaxation in terms of recruiting regional heads candidates. However, the beneficial impact is small, considering the timeframe of changing implementation schedule has only been postponed by three months, from September 23 to December 9, 2020. This schedule adjustment is necessary due to the increase of positive COVID-19 cases, which continues to grow until now. 
POLITICON : Jurnal Ilmu Politik Vol.3 No.2 ; Hal 185 - 205

Website : http://journal.uinsgd.ac.id/index.php/politicon

ISSN : 2685-6670 ( Online )

Quoting the statement published by International IDEA, (Andrian Habibi, 2020, p. 168), on the election and COVID-19 paper which was translated by the Association for Democracy (Perludem) becomes the electoral literature argument. Solutions of Policy have not been found. Indirectly, International IDEA provides advices yet leaves the options to continue with the election or to postpone until COVID-19 ends. Another potential conflict is the poor technical management which has resulted re-voting in several regions in Indonesia.

As mentioned above, the potential for conflicts occur in 2020 Local Elections includes several factors as: The practice of money politics which is disguised as a form of aid for the participants and parties involved in the election process to overcome COVID-19 prevention, knowing that the case in Indonesia is continuously growing. The decrease of participants due to COVID19 spread. The elections will make participants and all parties involved to be fully exposed in crowds, which increases the possibility of COVID-19 spread. The verification stage or process are prone to fraud in terms of candidate requirements. The suspensions of many stages which causes the delay of planned schedule, and the poor of technical management in every process which has resulted re-voting in several regions.

\section{Conflict Resolution of Simultaneous Local Elections in 2020}

Effective conflict resolution can be formed if the causes of conflict are clearly identified so that under these circumstances, solution can be determined according to the needs of the conflicting parties. framework used to understand conflict (Humaedi, et al, 2018).

Each head regional and provincial election always have conflict, indicating political maturity of the community is unstable and questionable. Some of the main problems that cause conflict are when the election stages are determined by the Regional General Elections Commission and their implementation begins. With the development of regional head election process, various issues have emerged, from the registration process, data 
collection, registration and candidate requirements, distribution of voter cards, to restating the results of the count. We often hear about racial, ethnic and religious issues known as SARA and money politics, these are examples of classic issues among the people. It happens when election momentum occurs yet complicated to prove and trace. This kind of conflict is inevitable. Conflicts that occur at all levels of society originate and lead to a decrease in power and authority, before leading to violence. There are several signs requires attention, in-depth research and analysis to find out the key factors, so we should find the best solution for smooth and successful local political process.

On issues with wide differences such as Medicare for all and COVID-19 restrictions candidates seeking rural votes will likely either need to embrace the extreme sides of health issues or appeal to independent voters, who remain largely divided on numerous issues. Rural Republicans generally lack confidence in the government's ability to run programs and are deeply opposed to greater government involvement in health care. Meanwhile, most rural Democrats have greater confidence in government and support a stronger role for the federal government. The role of government is a major issue that influences how rural voters perceive challenges at hand and where they believe help should come from (Lockman and Blendon 2020).

Conventional wisdom conceives of COVID-19 narrowly as a global health crisis requiring a medical response with a view to ensure health security. In Africa, the election has been postponed due to advance both democracy and human security in tandem. Meanwhile, failure to maintain the democracy human security balance may be bolster autocratisation in Africa (Matlosa 2021). However, in 2020 Wisconsin election produced a large natural experiment to help understand the transmission risks of severe respiratory syndrome coronavirus 2 (SARS-CoV-2). Taken together, it appears that voting in Wisconsin on April 7 was a low-risk activity based on the low fatality rate, the community risk such as the downstream cases generated, and since the reproduction number in Wisconsin has been hovering near the value of one for 
all (Leung, $\mathrm{Wu}$, et al 2020). The long lines of voters due to fewer polling locations in Wisconsin presidential primary election caused at least $10 \%$ increase in in-person per polling location is associated with an $18.4 \%$ increase in the COVID-19 positive test rate 2-3 weeks later (Cotti et al., 2021).

When it comes to the problem of money politics in democratic process in Indonesia, conflict resolution that can be applied is by conducting political education as early as possible. Political education is very important to develop adequate knowledge related to decision-making and the conscious and rational use of political rights. To eliminate the culture of money politics, it should start with political parties. The organizational governance of political parties should also be managed as good as possible, including the recruitment process that does not start with money cultures known as transactional politics. This is because the tradition of money politics is not only occur in the beginning of campaign period, but also during pre-election stage, and postelection stage.

Furthermore, one of the problem is related to low participant in the elections due to elders and vulnerable participants are prohibited to vote in prevention of COVID-19 spread, causing a public fear of COVID-19 spread is also considered as massive challenge for election organizers. However, House of Representatives (DPR), and the Government agreed to hold the Local Elections on December 9, 2020 in 270 regions throughout Indonesia. This decision underlies on Government Regulation in Lieu of Law (Perppu) No.2 of 2020 concerning the Local Elections signed by President Jokowi.

There are also several challenges in the implementation of election during pandemic that remains overshadowing the process. Although the government has prepared new normal regulations, the threat of COVID-19 transmission continues to shadow the KPU regulations regarding implementing the Local Elections also among the participants since the people are more focused on health and the economy in this time of the year. 
POLITICON : Jurnal Ilmu Politik Vol.3 No.2 ; Hal 185 - 205

Website : http://journal.uinsgd.ac.id/index.php/politicon ISSN : 2685-6670 ( Online )

In Regulation of General Elections Commission of Republic of Indonesia Number 6 of 2020 concerning the Implementation of Governors and Deputy Governors Elections, Regents and Deputy Regents, Mayors and Deputy Mayors Simultaneously Continued in Non-Natural Disaster Conditions Corona Virus Disease 2019 (COVID-19) Chapter VIII Part One Collection Voting Article 68 Paragraphs 1 and 2 page 61 regulates the Implementation of Voting and Vote Counting in Continued Simultaneous Elections to be carried out by implementing prevention and control health protocol with the following conditions:

1. Local Elections Commission members and Polling Stations enforcement officers are required to wear personal protective equipment covering the nose and mouth to the chin, disposable gloves, and face shields.

2. Participants are required to wear masks covering the nose and mouth to the chin area and prohibited to remove the masks under any circumstances.

3. Local Elections Commission provide disposable gloves for all participants that will be attending the election process.

4. Supervisors present at Polling Stations are required to wear masks covering the nose and mouth to the chin area, and disposable gloves all the time during the election process.

5. All participants, supervisor and other involved parties should always maintain the distance at least 1 meter between each other in voting and counting process.

6. Any form of physical contacts between every participants and other parties is highly prohibited.

7. The parties involved in the election should always provide adequate sanitation facilities such as hand sanitizers, running water and soap, also disinfectants and make sure the participants sanitized correctly. 
POLITICON : Jurnal Ilmu Politik Vol.3 No.2 ; Hal 185 - 205

Website : http://journal.uinsgd.ac.id/index.php/politicon

ISSN : 2685-6670 ( Online )

8. The supervisors and other involved parties should always limit the number of participants who will enter the vote station by calculating the capacity of Polling Stations and distance between participants in line to the vote station.

9. The participant should have personal stationery before entering the vote station.

10. The Local Election Commission members should have rapid tests and health checks implemented at least once, carried by regional parties in charge of health affair.

11. Local Elections Commission members, officers, participants, witnesses and supervisors should have body temperature checks before and after entering the election area.

Meanwhile, the process of re-voting held in several regions in Indonesia can also be classified as one of the contributing factors due to poor technical management related to underlying factors, such as the poor preparation of regional election organizers. It is believed that the organizers were expected to form extensive technical regulations within short period of time without proper preparations, causing a lot of issues regarding technical management during the elections.

In addition, the organizers poor understanding of law, or they have no authority to resist any form of pressure by the parties with higher authority, causing some polling stations to organize re-voting event. Adherence to mitigation measures is important not only to protect voters but also to protect poll workers, many of whom are older adults (Leidman et al 2020). The democracy atmosphere implementation would be different from previous over the years due to COVID-19 pandemic as its prediction. The study conducted by Sandi et al 2020 proved that the regional election could be implemented by following the Protocol Health Procedures with safe and healthy against COVID-19 (Sandi, Suprayitno, Jaya 2020). 
POLITICON : Jurnal Ilmu Politik Vol.3 No.2 ; Hal 185 - 205

Website : http://journal.uinsgd.ac.id/index.php/politicon

ISSN : 2685-6670 ( Online )

The implementation re-voting will inevitably rise to new issues that decrease the integrity of direct, public, free, confidential, honest and fair elections. Which needed as the basic of election principals. Thus, to minimize the occurrence of re-voting, the author concludes that election organizers should prepare the planning, organizing, implementing proper technical management and supervising the entire process of organizing elections at all times not only to decrease the issues but also to make sure it does not happen in the future, or any following elections in Indonesia.

\section{CONCLUSION}

The decision to hold elections during the COVID-19 pandemic is an issue that needs more attention. The main reason why the Pilkada is an issue is because there will be differences in people's views whether the election should be held during the COVID-19 pandemic or not. During the Pandemic, the possibility of conflict occurring in the Pilkada is getting bigger, not only making it harder to avoid, but will also cause more problems in society. The Pilkada will expose participants and all parties involved to being fully exposed to crowds, which increases the likelihood of the spread of COVID-19. The verification stage or process is prone to fraud in terms of candidate requirements. The delay of many stages led to delays in the planned schedule, and poor technical management of each process which resulted in re-voting in some areas.

The re-voting will inevitably raise new issues that degrade the integrity of direct, general, free, confidential, honest and fair elections. What is needed as a basis for selecting school principals. Thus, in order to minimize the occurrence of re-voting, the authors conclude that the EMB should prepare proper planning, organising, implementing technical management and supervising the entire process of holding the election at all times not only to reduce the problem but also to ensure it does not happen in the future, or the next election in Indonesia. 
POLITICON : Jurnal Ilmu Politik Vol.3 No.2 ; Hal 185 - 205

Website : http://journal.uinsgd.ac.id/index.php/politicon

ISSN : 2685-6670 ( Online )

\section{BIBLIOGRAPHY}

Andrian Habibi. (2020). Pemilihan Umum Di Tahun 2020. Jurnal Buletin Hukum dan Keadilan, 4(1).

Anggraini, S., Afrizal, \& Indraddin. (2019). REGULASI KONFLIK PEMILU (Studi Kasus Resolusi Konflik Pilkada 2015 dan Persiapan Pemilu 2019 di Kabupaten Sijunjung). JURNAL ANTROPOLOGI: ISU-ISU SOSIAL BUDAYA, 21(2).

Arnia, M. S. (2018). Democracy through election: a study on the conflict of norms in Aceh's election process. Journal of Southeast Asian Human Rights vol. 2 (1), 323-335.

Baccini, L, Brodeur, A, Weymouth, S. (2021). The COVID-19 pandemic and the 2020 US presidential election. Journal of Population Economics 34 (2), 739-767.

Chen, E, Chang, H, et al. (2021). COVID-19 misinformation and the 2020 US presidential election. The Harvard Kennedy School Misinformation Review.

Cotti, C., Engelhardt, B., et al. (2021). The relationship between in-person voting and COVID-19: evidence from the Wisconsin primary. Contemporary economic policy.

Fealy, G. (2020). Jokowi in the COVID-19 era: repressive pluralism, dynasticism, and the overbearing state. Bulletin of Indonesian Economic Studies vol. 56 (3), 301-323.

Fernandes, R., Susilawati, N., Muspita, R., et al. (2020). Voter education for the deaf during the COVID-19 pandemic. PalArch's Journal of Archaeology of Egypt/Egyptology vol 17 (6), 10518-10528.

Giomonni, T., Loumeau, G. (2020). Lockdown and voting behavior: a natural experiment on postponed elections during the COVID-19 pandemic. Covid Economics vol 41, 69-99. 
POLITICON : Jurnal Ilmu Politik Vol.3 No.2 ; Hal 185 - 205

Website : http://journal.uinsgd.ac.id/index.php/politicon ISSN : 2685-6670 ( Online )

Greer, L. L., Jehn, K. A. (2007). The pivotal role of negative affect in understanding the effects of process conflict on group performance. Research on Managing Groups and Teams vol 10, 23-45.

Greer, L. L., Jehn, K. A., Mannix, E. A. (2008). Conflict transformation: a longitudinal investigation of the relationships between different types of intragroup conflict and the moderating role of conflict resolution. Small Group Research: Sage Publication vol 39 (278), 2-26.

Humaedi, et al. (2018). Resolusi Konflik Pilkada di Kota Cimahi Jawa Barat. Social Work Jurnal, 8(1), 103-113.

Interational Crisis Group. (2010). Indonesia: Mencegah Kekerasan dalam Pemilu Kepala Daerah Asia Report N¹97. Jakarta: International Crisis Group.

James, T.B., Alihodzic, S. (2020). When is it democratic to postpone an election? Elections during natural disasters, COVID-19, and emergency situations. Election Law Journal: Rules, Politics, and Policy 19 (3), 344362.

Jehamun, P. (2020, Juni 1). Kompleksitas Masalah Pilkada 2020 di Tengah Pandemi Covid-19. Retrieved Juni 12, 2021, from Bernasnews: https://bernasnews.com/kompleksitas-masalah-pilkada-2020-ditengah-pandemi-covid-19/

Johnson, A. F., Pollock, W., Rauhaus, B. (2020). Mass casualty

event scenarios and political shifts: 2020 election outcomes and the US COVID-

19 pandemic. Administrative Theory \& Praxis 42 (2), 249-264.

Kamil, M., Bist, A. S., et al. (2021). COVID-19: Implementation e-voting blockchain concept. International Journal of Artificial Intelligence Research vol. 5 (1).

Kuntjaraningrat. (1983). Manusia dan Kebudayaan di Indonesia. Jakarta: Jembatan.

Leidman, E., Hall, N. B. (2020). Adoption of strategies to mitigate transmission of COVID-19 during a statewide primary election-Delaware, 
POLITICON : Jurnal Ilmu Politik Vol.3 No.2 ; Hal 185 - 205

Website : http://journal.uinsgd.ac.id/index.php/politicon

ISSN : 2685-6670 ( Online )

September 2020. Morbidity and Mortality Weekly Report 69 (43), 1571.

Leung, K, Wu, J, T, et al. (2020). No detectable surge in SARS-CoV-2 transmission attributable to the April 7, 2020 Wisconsin election. Americal Journal of Public Health 110 (8), 1169-1170.

Lockman, A, Blendon, R, J. (2020). Rural US voters' views on health policy and COVID-19 before the 2020 election. JAMA Health Forum 1 (9), e201123, 2020.

Marisa, H., Pornauli, A., Indra, A., Aurora, A. (2020). The regional

head elections (PILKADA) 2020 during COVID-19 pandemic: a projection.

JOELS: Journal of Election and Leadership vol. 1(2), 64-48.

Matlosa, K. (2021). Elections in Africa during Covid-19: the tenous balance between democracy and human security. Politikon 48 (2), 159-173.

Mindes, G. (2006). Teaching young children social studies. USA: Plaeger Publishers.

Moleong, L. J. (2006). Metodologi Penelitian Kualitatif. Bandung: Remaja Rosdakarya.

Norris, K., Gonzales, C. (2020). COVID-19, health disparities and the US election. EClinicalMedicin: Commentary vol 28.

Nursalim, M. P. (2019). Mitos di media sosial terkait pilpres 2019. Piktotrial: Journal of Humanities vol. 1 (1), 1-14.

Prabowo, H., Syafri, W., Juanda, J. (2020). Pandemic at the polls: preparement and arrangement of Indonesian regional the election in the midst of COVID-19. International Journal of Management (IJM) vol 11 (12).

Rahmiati, D. (2020, November 8). Pusat Penelitian Politik. Retrieved Juni 12, 2021, from Potensi Konflik Sosial Pilkada 2020: http://www.politik.lipi.go.id/kolom/kolom-2/politiknasional/1427-potensi-konflik-sosial-pilkada-2020

Ritzer, G., \& Goodman, D. J. (2004). Teeori Sosiologi Modern. Jakarta: Perenda Media. 
POLITICON : Jurnal Ilmu Politik Vol.3 No.2 ; Hal 185 - 205

Website : http://journal.uinsgd.ac.id/index.php/politicon ISSN : 2685-6670 ( Online )

Rosanti, R. (2020). Pandemic at the polls: how to prepare the elections post COVID-19 (towards Indonesia Local Elections in 2020). Jurnal Academia Praja vol. 3 (2), 147-167.

Royadi, D., Susiana, N., Khumaida, F. A. (2019). Effectiveness management of qualitative research in writing scientific papers. Aptisi Transaction on Management (ATM) vol 3 (1), 84-90.

Sandi, J. R. A., Suprayitno, J., Jaya, I. (2020). Public perception of the implementation of simultaneous regional head election 2020 during COVID-19 pandemic in Palangka Raya Regency. Budapest International Research and Critics Instute-Journal (BIRCI-Journal) vol 3, 3333-3340.

Sarjan, Mulya, K. A., \& Chadijah, S. (2020). Problematika Dan Teknis Penyelengaraan Pemilihan Kepala Daerah Pada Masa Pandemi Covid 19. Jurnal Ilmu Hukum, 3(1).

Strathdee, S, A, Davies, S, C, Marcelin, J, R. (2020). Confronting antimicrobial resistance beyond the COVID-19 pandemic and the 2020 US election. The Lancet 396 (10257), 1050-1053.

Sucipto, T. I. (2020, Juni 20). Lima Potensi Masalah di Pilkada 2020. Retrieved Juni 12, 2021, from medcom.id: https://www.medcom.id/pilkada/news-pilkada/lKYxJEQk-limapotensi-masalah-di-pilkada-2020

Surbakti, R. (1992). Memahami Ilmu Politik. Jakarta: PT Gramedia Widiasarana.

UNDP. (2009). Retrieved from Election An Conflict revention A Guide To Analysis,Planning And Programming.

Wehr, P. (1979). Conflict Regulation. Boulder: CO: Westview.

Wijaya, C. (2020). PSBB Jakarta mulai 10 april selama dua minggu, namun pakar menyebut hasil efektif satu bulan untuk tekan COVID-19. Retrieved August 8, 2021, from bbc.com/Indonesia/Indonesia52194441. 
POLITICON : Jurnal Ilmu Politik Vol.3 No.2 ; Hal 185 - 205

Website : http://journal.uinsgd.ac.id/index.php/politicon ISSN : 2685-6670 ( Online )

Whitehead, L. (1989). The Consolidation of FragileDemocracies? In R. P. (ed), Democracy in the Americas. New York: New York Holmes.

Zeiton, J. D., Faron, M, et al. (2020). Reciprocal association between participation to a national election and the epidemic spread of COVID19 in France: nationwide observational and dynamic modeling study. MedRxiv.

Zuhro, R. S. (2019). Demokrasi Dan Pemilu Presiden 2019. Jurnal Penelitian Politik, 16(1), 69-81. 